\title{
Some Pycnogonida (Arthropoda: Chelicerata) from the "Paulo Young" Invertebrate Collection (CIPY) of the Federal University of Paraíba (UFPB), Brazil
}

\author{
Rudá Amorim Lucena ${ }^{1} \&$ Martin Lindsey Christoffersen ${ }^{1,2}$
}

(1) Universidade Federal da Paraíba - Campus I, Centro de Ciências Exatas e da Natureza, Departamento de Sistemática e Ecologia, Programa de Pós-Graduação em Ciências Biológicas (Zoologia), Cidade Universitária, João Pessoa 58051-900, Paraíba, Brazil. E-mail: rudalucena15@gmail.com

(2) Universidade Federal da Paraíba - Campus I, Centro de Ciências Exatas e da Natureza, Departamento de Sistemática e Ecologia, Laboratório de Filogenia de Metazoa (não-insetos), Cidade Universitária, João Pessoa 58051-900, Paraíba, Brazil. E-mail: martinlc.ufpb@gmail.com

Lucena R.A. \& Christoffersen M.L. (2018) Some Pycnogonida from the "Paulo Young" Invertebrate Collection (CIPY) of the Federal University of Paraíba (UFPB), Brazil. Pesquisa e Ensino em Ciências Exatas e da Natureza, 2(2): 105-118. http://dx.doi.org/10.29215/pecen.v2i2.1065

Academic editor: Marcio Bernardino da Silva. Received: 14 June 2018. Accepted: 19 October 2018. Published: 28 December 2018.

\section{Alguns Pycnogonida da Coleção de Invertebrados "Paulo Young” (CIPY) da Universidade Federal da} Paraíba (UFPB), Brasil

Resumo: O estudo da biodiversidade é de extrema urgência, devido principalmente à velocidade dos impactos ambientais que atingem principalmente o meio marinho. Devido a essas alterações, parte da biota encontra-se inacessível em meio natural. Neste sentido as coleções biológicas aparecem como ponto chave, servindo de bancos de dados imprescindível para trabalhos de Taxonomia, Sistemática e Biogeografia, além de diversas outras áreas do conhecimento. As coleções biológicas no Brasil sofrem com a falta de apoio financeiro, falta de recursos humanos (tanto técnicos quanto científicos) e a dificuldade de acesso a informação que nelas está contida. A Coleção de Invertebrados Paulo Young (CIPY) conta hoje com mais de 18.000 lotes tombados dos mais variados grupos de invertebrados marinhos, desde espojas até tunicados. A seção de Pycnogonida, apesar de não possuir tantos exemplares quanto algumas outras coleções, tem sido foco de estudos nos últimos anos, revelando uma grande quantidade de informações importantes para o conhecimento científico, com a descoberta de novas espécies e novos registros para o Brasil. O presente trabalho tem como objetivo divulgar a CIPY, e parte do seu acervo de Pycnogonida que ainda não havia sido publicado.

Palavras chave: Pantopoda, aranha do mar, coleção zoológica, bentos.

Abstract: Biodiversity studies are increasingly urgent, due mainly to the speed with which anthropic degredation is affecting the environment, marine localities in particular. Due to these human impacts, part of the marine biota is becoming increasingly unavailable in natural environments. Biological collections thus are of key importance, functioning as data bases for studies in Taxonomy, Systematics and Biogeography, as well as for several applied areas of research. Biological collections in Brazil suffer from lack of financial support, lack of human resources (both technical and scientific) and are difficult to access by the scientific cummunity. The Invertebrate Collection "Paulo Young" (CIPY) contains more than 18.000 identified and numbered samples of several marine invertebrates, from sponges to tunicates. The pycnogonid section, although less numerous than many other animal groups, has been the focus of attention in recent years. Several new species and new records have been reported from Brazil. The aim of the present paper is to disclose the CIPY reference collection, recording the Pycnogonida collection that was not the subject of previous publications.

Key words: Pantopoda, sea spiders, zoological collection, benthos. 


\section{Introduction}

Pycnogonida Latreille, 1810 are exclusively marine chelicerates (Du Bois-Reymond Marcus 1952). They are cosmopolitan in distribution, occurring from the intertidal zone to the deep sea (Bamber 2007). More than 1340 species have been described (Munilla León \& SolerMembrives 2009; Appeltans et al. 2012). Yet, knowledge of the group remains scarce, particularly in Brazil (Lucena \& Christoffersen 2018a). Some factors perhaps explain the general lack of interest in this group, such as their low abundance, efficient camouflage, small size with aberrant forms, and lack of economic relevance (Arango 2003). Shallow, warm-water species are most neglected due mainly to their small size, cryptic habits, and irregular occurrences (Arango \& Krapp 2007).

Biological collections are material databases of specimens that function as indispensable tools in the studies of taxonomists (França \& Callisto 2007). They also provide basic knowledge in areas from Agronomy to Medicine (Magalhães et al. 2005). Collections are considered to represent the most important source of knowledge for mapping the composition, the spatial and temporal distribution, and the world biodiversity as a whole (Magalhães et al. 2005; Egler et al. 2006; França \& Callisto 2007).

The first natural history museum was founded in 1719 by the Czar Peter the Great, reflecting the habit of collecting and accumulating biological material (Pyke \& Ehrlich 2010; Senna et al. 2013). The first Brazilian scientific collection was founded in 1818, it was called “Casa dos Pássaros”, giving rise to the National Museum in Rio de Janeiro (Zaher \& Young 2003). The first institutional collections in northeastern Brazil only appeared in the 1950s and 1960s: the Ictiological and Carcinological Collections of the "Instituto de Ciências do Mar LABOMAR", and other smaller zoological collections. After the 1970s several collections were initiated, including the Invertebrate Collection "Paulo Young" (CIPY) at the Federal University of Paraíba (Senna et al. 2013).

Brazilian zoological collections contain an inexhaustible amount of information (Zaher \& Young 2003). They harbor several taxa that have never been organized or studied systematically (Lewinsohn \& Prado 2006). The Pycnogonida are a case in point. Despite having been well studied from 1940 to 1970 (see Lucena \& Christoffersen 2018a), most of this studied material has been subsequently lost. Furthermore, most large collections in Brazil do not have significant representatives of pycnogonids or fail to provide information regarding this group in their collections. Regarding these particulars, the Invertebrate Collection "Paulo Young" (CIPY) is outstanding. It has a significant collection of pycnogonids that has permitted the production of a series of recent publications about Pycnogonida. The aim of this paper is to reveal to the public at large the status of knowledge about the Brazilian pycnogonid fauna. For this we list here the main species deposited in the CIPY coming from other regions than the northeast of Brazil.

\section{Material and Methods}

The material is deposited in the Paulo Young Invertebrate Collection (Coleção de Invertebrados Paulo Young - CIPY) at "Universidade Federal da Paraiba (UFPB)", and encompasses specimens of Pycnogonida collected from 1969 to 2015 in southeastern, eastern, and northeastern Brazil, as well as in some other countries.

Identification of the specimens followed Marcus (1940), King (1974) and Müller \& Krapp (2009).

\section{The Invertebrate Collection "Paulo Young" (CIPY)}

The CIPY was officially created in 2004, after the death of an oustanding pioneer who collected the initial material of this collection in significant quantities in northern and northeastern Brazil. However, the initial establishment of this collection can be traced back to 1976, when the first undergraduate class in the Biological Sciences was initiated at the Federal 
University of Paraíba. Two zoology prof. Conceição Farias and prof. Priscilla Dijck, began a collection of crustaceans and mollusks, respectively, from specimens collected on Restinga Island, estuary of the north Paraíba River, municipality of João Pessoa, State of Paraíba. The CIPY is now located next to the Paulo Young laboratory for the study of invertebrates (LIPY), in the Department of Systematics and Ecology (DSE), Federal University of Paraíba (UFPB), Campus I, in João Pessoa.

Paulo Young arrived in João Pessoa in 1980 and became a Master student in the first class of students in the Graduate Program of the Federal University of Paraíba. At the time one of the co-authors of this paper (Martin L. Christoffersen) coordinated a major program for the collection of marine invertebrates along the coastline of north and northeastern Brazil, financed by “Coordenação de Desenvolvimento Científico e Tecnológico”. Paulo Young participated actively in collecting expeditions during the following two years and thus contributed substantially for the formation of our present zoological collection.

The collection presently contains 18.161 identified and registered samples of several invertebrates such as Porifera (776), Cnidaria (1,120), Nematoda (02), Platyhelminthes (02), Mollusca (3812), Polychaeta (1736), Clitellata (52), Echiura (27), Bryozoa (134), Sipuncula (170), Crustacea (7375), Echinodermata (2292), Tunicata (342), and Pycnogonida (321 lots). A significant amount of material remains to be identified, studied, and incorporated into the distinct sections of this collection.

The section of Pycnogonida presently has 1020 specimens belonging to 54 species, with some material remaining to be processed. This material comes from several collecting expeditions from 1969 to 2016, in different habitats along the Brazilian coastline, predominantly in coral reefs and sandy bottoms ranging from the intertidal zone to the depth of about $50 \mathrm{~m}$. There is material from all northeastern Brazil, from some states in the southeast (Espírito Santo and São Paulo), south (Paraná), and even from abroad (France and Singapore).

Most of this material was identified and processed for future publications. About a quarter of the pycnogonid specimens presently deposited in the CIPY has been object of scientific publications (see Lucena et al. 2015, 2017; Lucena \& Christoffersen 2017, 2018b; present paper) (Table 1).

Table 1. Species of pycnogonids deposited in the CIPY appearing in published scientific articles. Reg. n. = Registration number.

\begin{tabular}{|c|c|c|}
\hline Superfamily/Family & Species & Reg. n. (UFPB.PYC-) \\
\hline \multicolumn{3}{|l|}{ Ascorhynchoidea } \\
\hline \multirow[t]{5}{*}{ Ammotheidae } & Achelia sawayai Marcus, 1940 & $256 ; 257$ \\
\hline & Ammothella rugulosa Verril, 1900 & 258 \\
\hline & Ammothella sp. & $253 ; 254$ \\
\hline & Tanystylum isabellae Marcus, 1940 & 255 \\
\hline & Tanystylum orbiculare Wilson, 1878 & $250 ; 251$ \\
\hline Family incertae sedis & Pigrogromitus timsanus Calman, 1927 & 096 \\
\hline \multicolumn{3}{|l|}{ Nymphonoidea } \\
\hline Callipallenidae & Callipallene abrolhiensis Lucena \& Christoffersen, 2017 & $\begin{array}{l}137 ; 138 ; 139 ; 140 ; 142 ; \\
143\end{array}$ \\
\hline Nymphonidae & Nymphon gracile Leach, 1814 & $259 ; 260$ \\
\hline Pallenopsidae & Pallenopsis fluminensis (Krøyer, 1844) & $005 ; 023 ; 024$ \\
\hline \multicolumn{3}{|l|}{ Phoxichilidoidea } \\
\hline Endeidae & Endeis sp. & 252 \\
\hline \multirow[t]{3}{*}{ Phoxichilidiidae } & Anoplodactylus batangensis (Helfer, 1938) & $\begin{array}{l}008 ; 028 ; 034 ; 043 ; 053 \text {; } \\
097 ; 098 ; 135 ; 141 ; 144 \text {; } \\
150 ; 173\end{array}$ \\
\hline & Anoplodactylus californicus Hall, 1912 & $\begin{array}{l}099 ; 100 ; 149 ; 151 ; 168 ; \\
182 ; 218 ; 219 ; 220 ; 221 ; \\
244\end{array}$ \\
\hline & Anoplodactylus eroticus Stock, 1968 & $\begin{array}{l}017 ; 061 ; 064 ; 101 ; 102 ; \\
120 ; 120 ; 121 ; 122 ; 131 ; \\
166 ; 216\end{array}$ \\
\hline
\end{tabular}


Table 1. Species of pycnogonids deposited in the CIPY appearing in published scientific articles. Reg. n. = Registration number (continued).

\begin{tabular}{lll}
\hline Superfamily/Family & \multicolumn{1}{c}{ Species } & \multicolumn{1}{c}{ Reg. n. (UFPB.PYC-) } \\
\hline & Anoplodactylus evelinae Marcus, 1940 & $103 ; 104 ; 105 ; 106 ; 107 ;$ \\
& $108 ; 109 ; 128 ; 170$ \\
& Anoplodactylus ganchiformis Lucena \& Christoffersen, 2018 & $217 ; 222 ; 242 ; 243$ \\
Anoplodactylus insignis (Hoek, 1881) & 110 \\
Anoplodactylus mirim Lucena, de Araújo \& Christoffersen, & $006 ; 066 ; 067 ; 068 ; 085 ;$ \\
2015 & $124 ; 165 ;$ \\
Anoplodactylus monotrema Stock, 1979 & $127 ; 129$ \\
Anoplodactylus petiolatus (Krøyer, 1844) & 126 \\
Anoplodactylus ricardoi Lucena \& Christoffersen, 2018 & $134 ; 245$ \\
Anoplodactylus stictus Marcus, 1940 & $111 ; 112 ; 113 ; 114 ; 115 ;$ \\
\end{tabular}

\title{
Results
}

\author{
Pycnogonida Latreille, 1810 \\ Ascorhynchoidea Pocock, 1904 \\ Ammotheidae Dohrn, 1881 \\ Achelia Hodge, 1864 \\ Achelia sawayai Marcus, 1940 \\ Figure 1A
}

Material examined: Brazil. [2`] UFPB.PYC-256, Praia Domingos Dias, Ubatuba, São Paulo, Brazil, col. E. Boffi, April 1969 to May 1970; [1 +] UFPB.PYC-257, Praia do Lamberto, Ubatuba, São Paulo, Brazil, col. E. Boffi, April 1969 to May 1970.

Distribution: Pantropical. Brazil (SP, off RJ, ES) to USA (Georgia); west coast of Africa; Madagascar; Indonesia; Papua-New Guinea; Fiji Islands; Society Archipelago.

Remarks: This is one of the most frequent species recorded in shallow waters in the Eastern Atlantic.

\section{Ammothella Verrill, 1900 \\ Ammothella rugulosa Verril, 1900 \\ Figure 1B}

Material examined: $[1 \hat{\jmath}, 2 \uparrow]$ UFPB.PYC-258, Praia do Tenório-Grande, Ubatuba, São Paulo, Brazil, col. E. Boffi, April 1969 to May 1970.

Distribution: Brazil (SP, RJ) to USA (Florida); Curaçao; Aruba; Bonaire; Mexico (Caribbean).

Remarks: Apparently restricted to the Western Atlantic, Ammothella rugulosa presents considerable morphological variation, being frequently misidentified with Ammothella appendiculata (Dohrn, 1881) (Stock 1992a). The main diagnostic characters of the species are: having a short ocular tubercule, and having the two articles of the scape of the same size (Child 1982) (arrows in Figure 1B).

\section{Ammothella sp. \\ Figure 1C}


Material examined: [1 juv.] Araçá, UFPB.PYC-253, São Sebastião, São Paulo, Brazil, 22 June 2012; [1 juv.] UFPB.PYC-254, Praia Grande, São Sebastião, São Paulo, Brazil, col. R.A. Lucena \& P. Gnaspini, intertidal, 05 September 2013.

Distribution: Brazil (SP).

Remarks: It was not possible to identify these young specimens to species level. These specimens are small and have the trunk segmentation complete, lateral processes separated by less than their diameter, ovigers and palps not completely developed and the chelifores are complete.

Tanystylum Miers, 1879

Tanystylum isabellae Marcus, 1940

Figure 1D

Material examined: [1 1 ] UFPB.PYC-255, Ponta do Guaecá, São Sebastião, São Paulo, Brazil, col. CEBIMar, intertidal, among algae, 04 September 2013.

Distribution: Brazil (SP, RJ, ES); Colombia (Atlantic); Virgin Islands; Bermudas; Democratic Republic of the Congo; Papua-New Guinea.

Remarks: This species is frequently recorded along the Western Atlantic. The species is characterized for having a proboscis that narrows gradually beyond the middle of its length. It differs from Tanystylum acuminatum Stock, 1954, a very similar species, which has the proboscis narrowing only at its distal fourth.

\section{Tanystylum orbiculare Wilson, 1878}

Figure 1E

Material examined: [1 1 ] UFPB.PYC-250, Ilha da Cotinga, Paranaguá, Paraná, Brazil, 03 January 2013; [1 $\overbrace{}^{\lambda}, 5$ ㅇ] UFPB.PYC-251, Iatch Club, Paranaguá, Paraná, Brazil, 03 January 2013.

Distribution: Argentina; Brazil (SP, RJ, ES); Venezuela; São Bartolomeu; Saint Martin; Gulf of Mexico; Cuba; Mexico (Atlantic); USA (Florida, Texas, South and North Carolina, Georgia, New York, Virginia, Massachusetts, Oregon, California); Bermudas; Azores; Morocco; Portugal; Mediterranean.

Remarks: This species presents considerable morphological variation, in the shape of the proboscis, ovigers, abdomen and palps. The palps present the biggest variations, and may have ranging from four to six articles (Child 1990). Marcus (1940) and Stock (1992a) characterized Brazilian specimens as having mainly five articles in the palps, and a more robust proboscis. Specimens examined by us differ only in having the abdomen erect and slightly longer (arrow in Figure 1E), and for having a long terminal seta on the chelifores.

\section{Family incertae sedis \\ Pigrogromitus Calman, 1927 \\ Pigrogromitus timsanus Calman, 1927 \\ Figure 1F}

Material examined: [2 $\left.{ }^{\Uparrow}\right]$ UFPB.PYC-096, Padang Buoy, Singapore, col. S. Lee, 23 July 2012.

Distribution: Pantropical. Curaçao, Colombia, Panama, USA (Florida, Hawaii), Mediterranean, Red sea, Australia, Indonesia, Singapore, Hong Kong, Japan. 
Remarks: The pantropical distribution may be due to introduction from other regions by shipping traffic. Their origin is perhaps the Indo-Pacific, where they are most common (Stock 1992b). Despite the large number of citations in the Indo-Pacific, this is the first record of Pigrogromitus timsanus for Singapore.

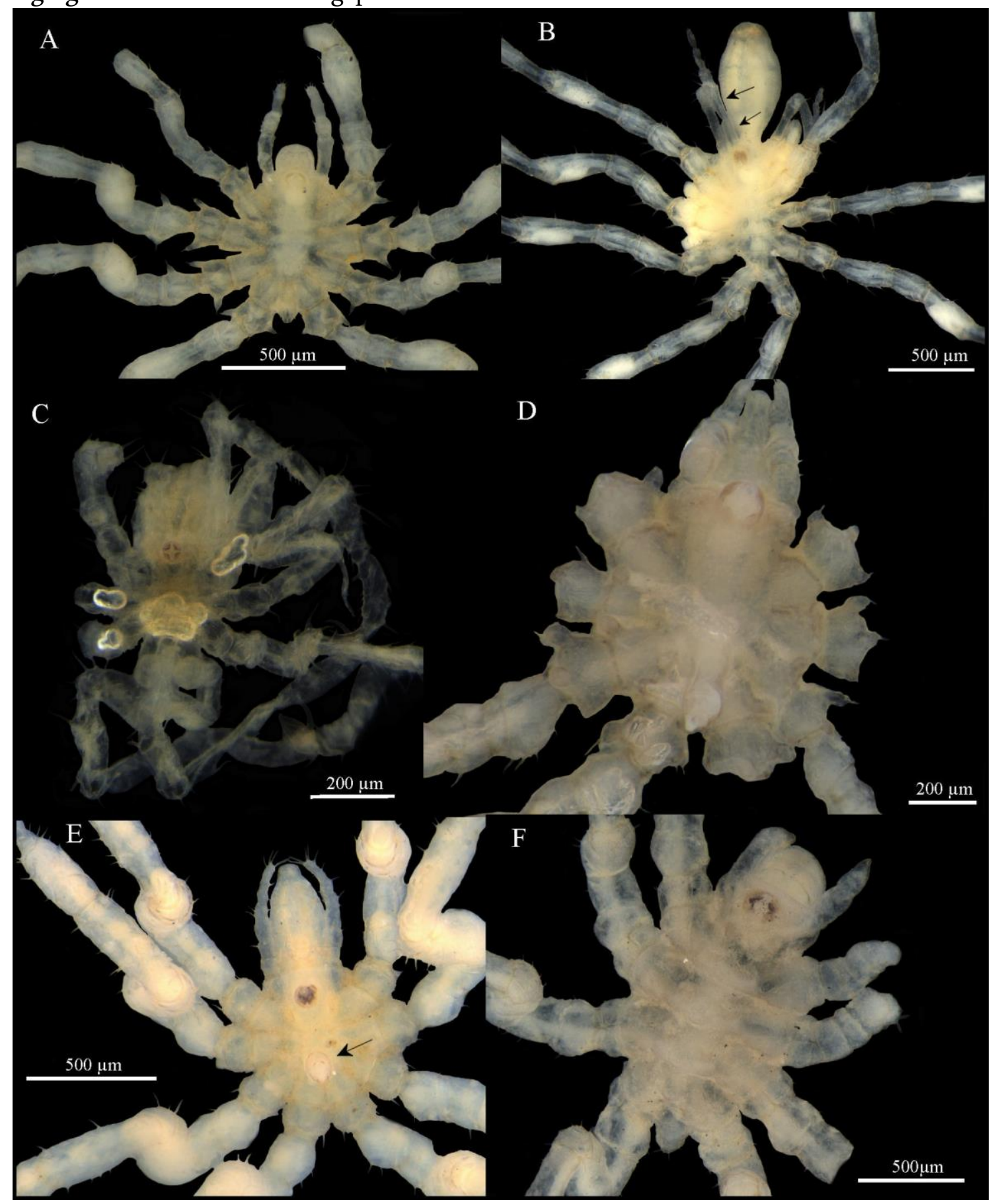

Figure 1. Some pycnogonids from CIPY: A. Achelia sawayai; B. Ammothella rugulosa (articles of chelifores - arrows); C. Ammothella sp.; D. Tanystylum isabellae; E. Tanystylum orbiculare (abdomen - arrows); F. Pigrogromitus timsanus.

Nymphonoidea Pocock, 1904

Nymphonidae Wilson, 1878

Nymphon Fabricius, 1794

Nymphon gracile Leach, 1814

Figure 2B 
Material examined: [2 $\left.{ }^{\lambda}\right]$ UFPB.PYC-259, Luc-sur-Mer, Normandy, France, col. A.R. Bessa, 02 April 2014; [1 $\left.\oint^{\Uparrow}\right]$ UFPB.PYC-260, Luc-sur-Mer, Normandy, France, col. A.R. Bessa, 02 April 2014.

Distribution: Atlantic and Mediterranean European waters (Esquete et al. 2013).

Remarks: Nymphon gracile occurs in littoral zones of Europe during the summer, being one of the most common species in shallow waters (King \& Jarvis 1970; King 1986).

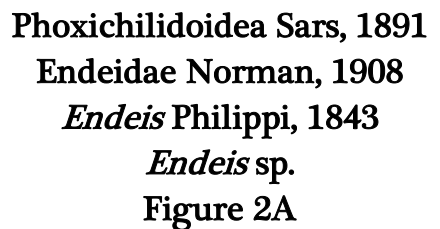

Material examined: [1 juv.] UFPB.PYC-252, Araçá, São Sebastião, São Paulo, Brazil, 22 June 2012.

Distribution: Brazil (SP).

Remarks: This genus is difficult to identify (Child 1992). Females are very hard to distinguish when not accompanied by males (Stock 1968). A character largely used to separate species is the quantity of pores in the cement gland (Marcus 1940). However, because the examined specimen is a juvenile, these structures are not present yet and it becomes impossible to identify the species.

This is a small, transparent species, with long, well separated legs. There are long terminal setae on the femur and the tibia. The propodus has three robust spines on the heel and six small spines on the sole. Only the first article of the ovigers are formed. The segmentation of the trunk is complete, yet quite subtle. The lateral processes are separated by a distance/space almost twice their diameter, with two-three small setae along their distal margins. The ocular tubercule is pointed. The abdomen is small.

\author{
Phoxichilidiidae Sars, 1891 \\ Anoplodactylus Wilson, 1878 \\ Anoplodactylus evelinae Marcus, 1940 \\ Figure 2C
}

Material examined: [1 9 ] UFPB.PYC-106, Praia do Lamberto, Ubatuba, São Paulo, Brazil, col. E. Boffi, April 1969 to May 1970; [2§] UFPB.PYC-107, Praia do Tenório/Praia Grande, Ubatuba, São Paulo, Brazil, col. E. Boffi, April 1969 to May 1970; [1 đ̊] UFPB.PYC-108, Ponta do Guaicá, São Sebastião, São Paulo, Brazil, col. CEBIMar res. Group 04 Sep 2013; [1 ] UFPB.PYC-109, Pier da Figueira, São Sebastião, São Paulo, Brazil, col. R.A. Lucena \& P. Gnaspini, 05 September 2013.

Distribution: Brazil (SC, SP, RJ, BA, AL); Colombia (Atlantic); Panama (Atlantic and Pacific); Saint Chrsitopher and Nevis; Anguilla; Jamaica; Belize; Mexico (Atlantic); USA (Florida); Congo.

Remarks: Easily distinguished from other species of the genus by having dorsally bifid and rounded tubercules on trunk segments one and two (arrows in Figure 2G), and one rounded tubercule above the insertion of the abdomen. This species has a widespread distribution distribution, being common along the Brazilian coast.

Anoplodactylus stictus Marcus, 1940

Figure 2D 
Material examined: [1 juv.] UFPB.PYC-113, Praia do Lamberto, Ubatuba, São Paulo, Brazil, col. E. Boffi, April 1969 to May 1970; [6へ̂, 3q, 8 juveniles] UFPB.PYC-114, Praia do Tenório/Praia Grande, Ubatuba, São Paulo, Brazil, col. E. Boffi, April 1969 to May 1970; [1 ] UFPB.PYC-115, Ponta do Guaicá, São Sebastião, São Paulo, Brazil, col. CEBIMar res.group 04 September 2013; [1 ] UFPB.PYC-116, Praia Grande, São Sebastião, São Paulo, Brazil, col. R.A. Lucena \& P. Gnaspini, 05 October 2013.

Distribution: Argentina; Brazil (off SC, PR, SP, RJ, ES, RN and CE).

Remarks: Despite having been recorded along almost the entire southeastern coastline of Brazil, this species is not easy to collect, being restricted to Brazil and north Argentina. It is very similar to Anoplodacctylus californicus Hall, 1912, a species with a larger distribution and higher abundance in Brazilian waters. It differs mainly by the presence of a tubercule on the lateral processes of the male and by the presence of a cutting lamina in the distal third of the propodal sole (Marcus 1940; Lucena \& Christoffersen 2018b).

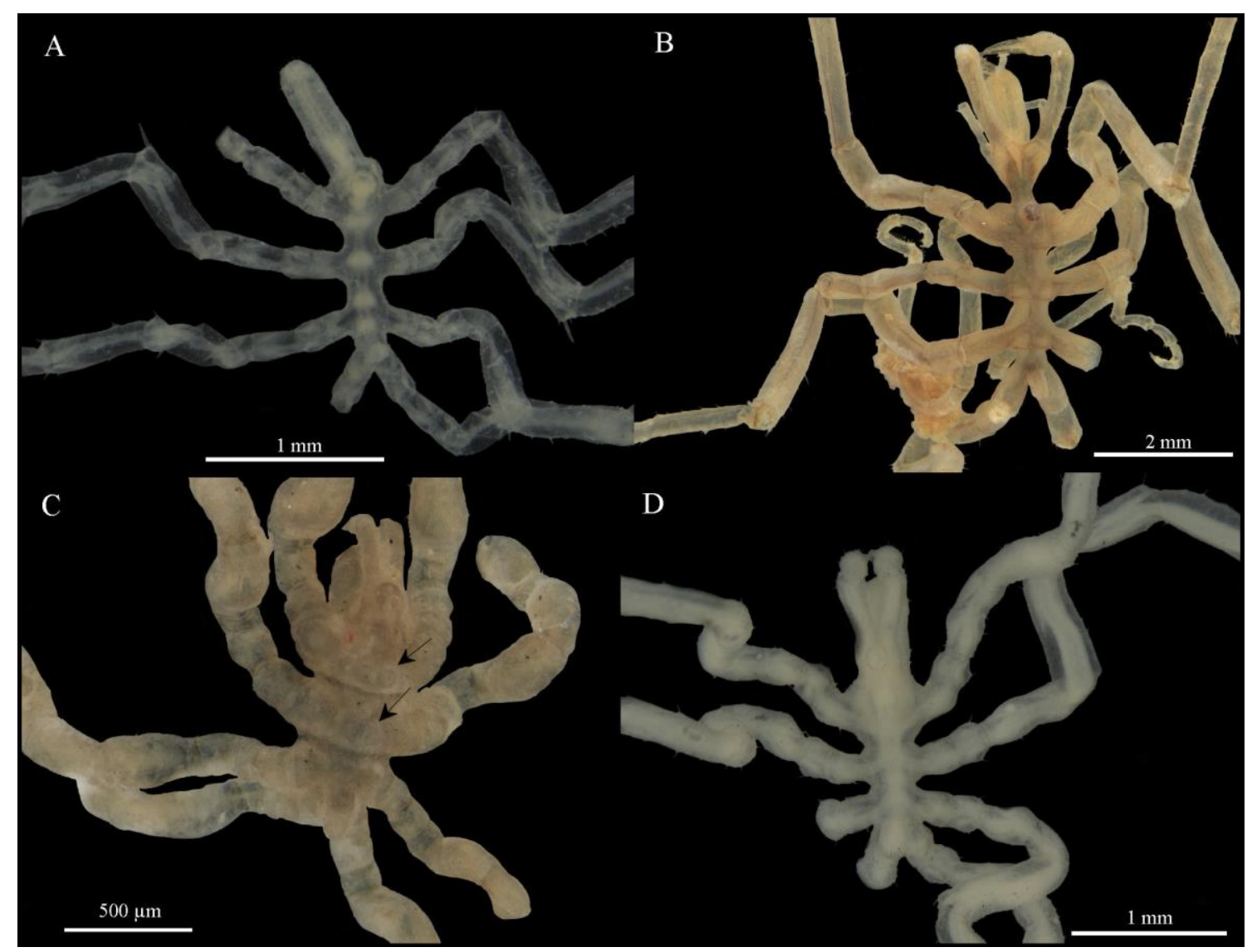

Figure 2. Some pycnogonids from CIPY: A. Endeis sp.; B. Nymphon gracile; C. Anoplodactylus evelinae (dorsal tubercles of trunk - arrows); D. Anoplodactylus stictus.

\section{Discussion}

Biological collections are an excellent way to record and study the Earth's biodiversity (Zaher \& Young 2003). They provide important data for biogeographical, taxonomic, ecological, genetic, and systematic studies (Zaher \& Young 2003; Magalhães et al. 2005). They also permit the planning of conservation and management policies (Magalhães et al. 2005). By documenting the distribution, changes in abundance, and extinction of species, it is possible to characterize and monitor environmental changes and their environmental impacts in the long run (Zaher \& Young 2003; Magalhães et al. 2005; Senna et al. 2013). 
The degradation of habitats, especially when the causes are anthropogenic, represents a great threat to biodiversity (Senna et al. 2013). Aquatic ecosystems are the most strongly impacted (França \& Callisto 2007), and the speed of degradation is so high that a large part of the diversity will have been lost before it is possible to document it (Zaher \& Young 2003). Due to environmental degradation and other difficulties in collecting, some species may be impossible to collect. Samples collected in the past and conserved in collections may represent the most precious, or even the only source of information of their existence (Winston 2007).

It has been estimated that more than 26 million specimens are deposited in Brazilian collections, which represents the largest collection of neotropical specimens in the world (Zaher \& Young 2003). However, a large part of these collections have never been organized or studied (Lewinsohn \& Prado 2006), due to a lack of specialists (Marques \& Lamas 2006). Considering that Taxonomy has lost space in the scientific domain since the 1980's as a consequence of the popularization of molecular biology (Senna et al. 2013), taxonomic studies are in decline, due to a decline in the number of specialists (Zaher \& Young 2003). This "taxonomic crisis", in combination with environmental degradation, intensifies the problem of biodiversity loss (Zaher \& Young 2003; Senna et al. 2013).

In northeastern Brazil, zoological collections represent medium-sized assemblages belonging to universities and some research institutions. Presently, there are more than 50 collections of different types of organisms. The most accessible collections are those of CIPY, at the Federal University of Paraíba, and in the Museum of Zoology, located in the Federal University of Bahia (Senna et al. 2013).

The CIPY represents intensive surveys conducted along the coastline of northern and northeastern Brazil conducted during the years of 1982-1983 and the result of sampling of 93 collecting stations distributed equidistantly along the entire continental shelf of the state of Paraíba conducted in 1983. Subsequently, the collection was gradually increased by individual contributions resulting from research projects, mainly dissertations and thesis work. A noteworthy contribution was the Project Biota, which sampled the state's coastline from 2007 to 2009. As a result of these efforts, 18.161 samples have been identified to species level and individually numbered, while large portion of collected material awaits further study.

The publication of biological information based on material deposited in the CIPY occurred punctually until the year 2000 (Young \& Christoffersen 1984; Veloso \& Melo 1993; Melo \& Veloso 2005). Papers were produced more systematically since 2008, dealing with diverse groups, such as Crustacea (Riul et al. 2008; Rodrigues et al. 2009), Polychaeta (Santos et al. 2008, 2010, 2011, 2014; de Assis et al. 2007, 2008a,b, 2012; Brito et al. 2013), Echinodermata (Gondim et al. 2013a,b, 2015; Prata et al. 2012, 2014a,b, 2016, 2017; Prata \& Christoffersen 2017), and Mollusca (Dias et al. 2013; Lima et al. 2013, 2017a; Lima \& Guimarães 2015; Lima \& Christoffersen 2016), include inventories of benthic macrofauna (Gondim et al. 2011) and biological associations (Lima et al. 2016, 2017b). However, most of the available information has not been published in scientific journals, having been cited only in monographies, dissertations, thesis and congress/conference abstracts, which makes access to this information more difficult for the scientific community.

For the section containing Pycnogonida, taxonomic studies began in 2015. Five papers were published by us on pycnogonids, they include the description four new species, a new record for the Atlantic Ocean, another new record for Brazil, a new record for Singapore, and several range extensions. Most published records are new for northeastern Brazil (Lucena et al. 2015, 2017; Lucena \& Christoffersen 2017, 2018b).

As with most other national collections, the study and maintainance of these specimens occurs under precarious conditions due to the lack of adequate physical infra-structure, lack of continuous resources for curational activities, and an insufficient number of specialists (Egler et al. 2006). Other than the sporadic obtainance of financial resources through approved projects, there is no permanent support for the formation and maintenance of Brazilian scientific collections by the developmental agencies. Most collections were begun by the initiative and effort of single or small groups of researchers. Because of the absence of long term institutional 
planning, most researchers have difficulties in obtaining the necessary resources for the continuous maintainace of these collections, particularly in the northeastern and central-western regions of the country (Zaher \& Young 2003; Egler et al. 2006). Furthermore, there is a lack of trained curators and technical support to adequately manage the existing collections (Egler et al. 2006).

As well as documenting biodiversity, biological collections may represent, at least in part, the solution for the problem of biodiversity loss. Biological collections play an important role in scientific disclosure to the community in general and in the formation of specialized human resources for the study of biodiversity (Senna et al. 2013). Recognition and awareness of the importance of biological collections could help individual managers to develop long term plans for training human resources and for the obtainment of continuous financial support for the maintainance of representative collections of our dwindling megadiversity.

\section{Acknowledgements}

The first author thanks the material donated by the researcher Anthony Rufino Bessa (Universidade Federal da Paraíba) and Dr. Lívia Moura de Oliveira (Universidade Federal do Paraná,). The second author acknowledges the productivity scholarship provided by GNPq since the 1980's, permitting the study and some financial support for our collection. We are grateful to the anonymous reviewers for critically reviewing the manuscript.

\section{References}

Appeltans W., Ahyong S.T., Anderson G., Angel M.V., Artois T., Bailly N., Bamber R., Barber A., Bartsch I., Berta A., Błazewicz-Paszkowycz M., Bock P., Boxshall G., Boyko C.B., Brandão S.N., Bray R.A., Bruce N.L., Cairns S.D., Chan Tin-Y., Cheng L., Collins A.G., Cribb T., CuriniGalletti M, Dahdouh-Guebas F., Davie P.J.F., Dawson M.N., De Clerck O., Decock W., De Grave S., de Voogd N.J., Domning D.P., Emig C.C., Erséus C., Eschmeyer W., Fauchald K., Fautin D.G., Feist S.W., Fransen C.H.J.M., Furuya H., Garcia-Alvarez O., Gerken S., Gibson D., Gittenberger A., Gofas S., Gómez-Daglio L., Gordon D.P., Guiry M.D., Hernandez F., Hoeksema B.W., Hopcroft R.R., Jaume D., Kirk P., Koedam N., Koenemann S., Kolb J.B., Kristensen R.M., Kroh A., Lambert G., Lazarus D.B., Lemaitre R., Longshaw M., Lowry J., Macpherson E., Madin L.P., Mah C., Mapstone G., McLaughlin P.A., Mees J., Meland K., Messing C.G., Mills C.E., Molodtsova T.N., Mooi R., Neuhaus B., Ng P.K.L., Nielsen C., Norenburg J., Opresko D.M., Osawa M., Paulay G., Perrin W., Pilger J.F., Poore G.C.B., Pugh P., Read G.B., Reimer J.D., Rius M., Rocha R.M., Saiz-Salinas J.I., Scarabino V., Schierwater B., Schmidt-Rhaesa A., Schnabel K.E., Schotte M., Schuchert P., Schwabe E., Segers H., SelfSullivan C., Shenkar N., Siegel V., Sterrer W., Stöhr S., Swalla B., Tasker M.L., Thuesen E.V., Timm T., Todaro M.A., Turon X., Tyler S., Uetz P., van der Land J., Vanhoorne B., van Ofwegen L.P., van Soest R.W.M., Vanaverbeke J., Walker-Smith G., Chad Walter T., Warren A., Williams G.C., Wilson S.P. \& Costello M.J. (2012) The magnitude of global marine species diversity. Current Biology, 22: 2189-2202. DOI: 10.1016/j.cub.2012.09.036

Arango C.P. (2003) Sea spiders (Pycnogonida, Arthropoda) from the Great Barrier Reef, Australia: new species, new records and ecological annotations. Journal of Natural History, 37: 2723-2772. DOI: 10.1080/00222930210158771

Arango C.P. \& Krapp F. (2007) A new species of Anoplodactylus (Arthropoda: Pycnogonida) from the Great Barrier Reef and discussion on the A. tenuicorpus-complex. Zootaxa, 1435: 19-24. DOI: 10.11646/zootaxa.1435.1.2

Bamber R.N. (2007) A holistic re-interpretation of the phylogeny of the Pycnogonida Latreille, 1810 (Arthropoda). Zootaxa, 1668: 295-312. DOI: 10.11646/zootaxa.1668.1.15

Brito R.J., de Assis J.E. \& Christoffersen M.L. (2013) First record of Chaetacanthus magnificus Grube, 1876 (Polychaeta: Polynoidae) from the northeast coast of Brazil, with an overview of its taxonomic history. Research Journal of the Costa Rican Distance Education University, 5: 25-32. 
Child C.A. (1982) Pycnogonida from Carrie Bow Cay, Belize. Smithsonian Contributions to the Marine Sciences, 12: 355-380.

Child C.A. (1990) Pycnogonida of the Western Pacific Islands. 8. Recent collections from islands of the Great-Barrier-Reef, Australia. Proceedings of the Biological Society of Washington, 103(2): 311-335.

Child C.A. (1992) Shallow-water Pycnogonida of the Gulf of Mexico. Memoirs of the Hourglass Cruises, 9: 1-86.

de Assis J.E., Alonso C. \& Christoffersen M.L. (2007) Two new species of Nicomache (Polychaeta: Maldanidae) from the Southwest Atlantic. Zootaxa, 1454: 27-37. DOI: 10.5281/zenodo.176321

de Assis J.E., Alonso C. \& Christoffersen M.L. (2008a) First record of Ficopomatus ushakovi (Pilai, 1960) (Serpulidae: Polychaeta) from the Western Atlantic. Revista Nordestina de Biologia, 19: 51-58.

de Assis J.E., Costa D.A. \& Christoffersen M.L. (2008b) First record of Hydroides similoides (Serpulidae: Polychaeta) from Brazil. Journal of the Marine Biological Association of the United Kingdom, 2: 1-3. DOI: 10.1017/S1755267208000316

de Assis J.E., Alonso C., Brito R.J., Christoffersen M.L. \& Santos A.S. (2012). Polychaetous annelids from the coast of Paraíba State, Brazil. Revista Nordestina de Biologia, 21: 3-44.

Dias T.L.P., Mota E.L.S., Gondim A.I., Oliveira J.M., Rabelo E.F., Almeida S.M. \& Christoffersen M.L. (2013) Isognomon bicolor (C.B. Adams, 1845) (Mollusca: Bivalvia): First record of this invasive species for the States of Paraíba and Alagoas and new records for other localities of Northeastern Brazil. Check List, 9: 157-161. DOI: 10.15560/9.1.157

Du Bois-Reymond Marcus E.B.R. (1952) A hermafroditic pantopod. Anais da Academia Brasileira de Ciências, 24(1): 23-30.

Egler I., Peixoto A.L., Barbosa M.R.V., Menezes M., Maia L.C., Vazoller R.F., Marinoni L., Canhos D.A.L. \& Santos M.M. (Coord.) (2006) Diretrizes e estratégias para a modernização de coleções biológicas brasileiras e a consolidação de sistemas integrados de informação sobre biodiversidade. Brasília: MCT/CGEE. 34 p. Available at: http://www.dpi.inpe.br/referata/arq/12 _candinha/11194.pdf (Acessed on 31.01.2018)

Esquete P., Bamber R.N., Moreira J. \& Troncoso J.S. (2013) Pycnogonids (Arthropoda: Pycnogonida) in Seagrass Meadows: The case of $\mathrm{O}$ Grove Inlet (Nw Iberian Peninsula). Thalassas, 29(1): 25-33.

França J.S. \& Castillo M. (2007) Coleção de macroinvertebrados bentônicos: ferramenta para o conhecimento da biodiversidade em ecossistemas aquáticos continentais. Neotropical Biology and Conservation, 2(1): 3-10.

Gondim A.I., Dias T.L.P. \& Christoffersen M.L. (2013a) Annotated checklist of echinoderms from Maranhão and Piauí States, northeastern Brazil. Check List, 9: 510-518. DOI: 10.15560/9.3.510

Gondim A., Alonso C., Dias T.L.P., Manso C.L.C. \& Christoffersen M.L. (2013b) A taxonomic guide to the brittle-stars (Echinodermata, Ophiuroidea) from the State of Paraíba continental shelf, Northeastern Brazil. ZooKeys, 307: 45-96. DOI: 10.3897/zookeys.307.4673

Gondim A.I., Dias T.L.P., Campos F.F., Alonso C. \& Christoffersen M.L. (2011) Benthic macrofauna from Areia Vermelha Marine State Park, Cabedelo, Paraíba, Brazil. Biota Neotropica, 11: 75-86. DOI: 10.1590/S1676-06032011000200009

Gondim A.I., Dias T.L.P. \& Christoffersen M.L. (2015) First record of basket stars Astrocyclus caecilia (Lütken, 1856) and Astrophyton muricatum (Lamarck, 1816) (Echinodermata, Ophiuroidea, Euryaida) for the State of Rio Grande do Norte, northeastern Brazil. Check List, 11: 1541-1546. DOI: 10.15560/11.1.1541

King P.E. (1974) British sea spiders: Synopses of the British Fauna, $\mathrm{n}^{0}$ 5. New York: The Linnean Society of London, Academic Press London and New York. 67 p.

King P.E. (1986) A revised key to the adults of litoral Pycnogonida in the British Isles. Field Studies, 6: 493-516

King P.E. \& Jarvis J.H. (1970) Egg development in a litoral pycnogonid Nymphon gracile. Marine Biology, 7: 294-304. 
Lewinsohn T.M. \& Prado P.I. (2006) Síntese do conhecimento atual de biodiversidade brasileira (p. 21-106). In: Lewinsohn T.M. (Org.). Avaliação do estado do conhecimento da biodiversidade brasileira. Volume 1. Brasília: Ministério do Meio Ambiente. 269 p.

Lima S.F.B. \& Guimarães C.R.P. (2015) New bathyal Anachis (Neogastropoda: Buccinoidea: Columbellidae) from the Southwestern Atlantic, and the designation of a lectotype for $A$. stricta (Watson, 1882). Zootaxa, 3949(3):445-450. DOI: 10.11646/zootaxa.3949.3.10

Lima S.F.B. \& Christoffersen M.L. (2016) Redescription and designation of a neotype for Caecum floridanum (Littorinimorpha, Truncatelloidea, Caecidae) with a characterization of the protoconch and growth stages. ZooKeys, 585:17-31. DOI: 10.3897/zookeys.585.7646

Lima S.F.B., Santos F.N. \& Absalão R.S. (2013) New Species of Caecum (Caenogastropoda: Rissooidea: Caecidae) from the Atlantic Coast of South America (Brazil) with a Description of the Protoconch and Growth Stages. Zoological Science, 30: 767-778. DOI:10.2108/zsj.30.767

Lima S.F.B., Lucena R.A., Santos G.M., Souza J.W., Christoffersen M.L., Guimarães C.R.P. \& Oliveira G.S.P. (2017a) Inventory of mollusks from the estuary of the Paraíba River in northeastern Brazil. Biota Neotropica, 17: 1-12. DOI: 10.1590/1676-0611-bn-2016-0239

Lima S.F.B., Queiroz V., Oliveira G.S.P., Christoffersen M.L. \& Guimaraes C.R.P. (2016) Stramonita brasiliensis (Gastropoda: Muricidae) living as inquiline on the shell of Pugilina tupiniquim (Gastropoda: Melongenidae). Bulletin of Marine Science, 92: 371-376. DOI: 10.5343/bms.2016.1003

Lima S.F.B., Lucena R.A., Queiroz V., Guimaraes C.R.P. \& Breves A. (2017b) The first finding of Ostrea cf. puelchana (Bivalvia) living as epibiont on Callinectes exasperates (Decapoda). Acta Scientiarum, Biological Sciences, 39(1): 79-85. DOI: 10.4025/actascibiolsci.v39i1.33629

Lucena R.A. \& Christoffersen M.L. (2017) Pycnogonida (Arthropoda) from the Abrolhos Archipelago, Brazil, including a new species of Callipallene Flynn, 1929. Marine Biodiversity, 47: 461-468. DOI: 10.1007/s12526-016-0481-6

Lucena R.A. \& Christoffersen M.L. (2018a) An annotated checklist of Brazilian sea spiders (Arthropoda: Pycnogonida). Zootaxa, 4370(2): 101-122. DOI: 10.11646/zootaxa.4370.2.1

Lucena R.A. \& Christoffersen M.L. (2018b) Anoplodactylus (Pycnogonida: Phoxichilidiidae) from Brazil, new records and two new species. Turkish Journal of Zoology, 42: 372-388. DOI: 10.3906/zoo-1712-1

Lucena R.A., Araújo J.P. \& Christoffersen M.L. (2015) A new species of Anoplodactylus (Pycnogonida: Phoxichilidiidae) from Brazil, with a case of gynandromorphism in Anolodactylus eroticus Stock, 1968. Zootaxa, 4000(4): 428-444. DOI: 10.11646/zootaxa.4000. 4.2

Lucena R.A., Lima S.F.B. \& Christoffersen M.L. (2017) First record of Pallenopsis fluminensis (Krøyer, 1844) (Pycnogonida: Pallenopsidae) for the coast of the State of Paraíba (northeastern Brazil). Pesquisa e Ensino em Ciências Exatas e da Natureza, 1(1): 19-27. DOI: 10.29215/pecen.v1i1.164

Magalhães C., Kury A.B., Bonaldo A.B., Hajdu E. \& Simone L.R.L (2005) Coleções de invertebrados do Brasil. Available at: http://www.cria.org.br/cgee/documentos/ColecoesdeIn vertebradosMagalhaesBonaldoKuryHadju.pdf (Acessed on 01.02.2018)

Marcus E. (1940) Os Pantopoda brasileiros e os demais sul-americanos. Boletim da Faculdade de Filosofia, Ciências e Letras, Universidade de São Paulo, 19(4): 3-179.

Marques A.C. \& Lamas C.J.E. (2006) Taxonomia zoológica no Brasil: Estado da arte, expectativas e sugestões de ações futuras. Papéis Avulsos de Zoologia, 46(13): 139-174. DOI: 10.1590/S0031-10492006001300001

Melo G.A.S. \& Veloso V.G. (2005) The Brachyura (Crustacea, Decapoda) of the coast of the State of Paraíba Brazil, collected by Project Algas. Revista Brasileira de Zoologia, 22(3): 796-805. DOI: $10.1590 / S 0101-81752005000300044$

Müller H.G. \& Krapp F. (2009) The pycnogonid fauna (Pycnogonida, Arthropoda) of the Tayrona National Park and adjoining areas on the Caribbean coast of Colombia. Zootaxa, 2319: 1-138. DOI: $10.13109 / 9783666530920.1$ 
Munilla León T. \& Soler-Membrives A. (2009) Check-list of the pycnogonids from Antarctic and sub-Antarctic waters: zoogeographic implications. Antarctic Science, 21(2): 99-111. DOI: 10.1017/S095410200800151X

Prata J. \& Christoffersen M.L. (2012) Holothuria Semerothuria surinamensis Ludwick, 1875. Check List, 8: 768-770. DOI: 10.15560/8.4.768

Prata J., Costa D.A., Manso C.L.C., Crispim M.C. \& Christoffersen M.L. (2017) Echinodermata associated to rodoliths from Seixas Beach, State of Paraíba, Northeast Brazil. Biota Neotropica, 17: 1-11. DOI: 10.1590/1676-0611-bn-2017-0363

Prata J. \& Christoffersen M.L. (2017) Checklist of the Holothuroidea (Echinodermata) from the State of Paraíba, Brazil. Pesquisa e Ensino em Ciências Exatas e da Natureza, 1: 45-59. DOI: 10.29215/pecen.v1i1.176

Prata J., Dias T.L.P. \& Christoffersen M.L. (2014a) Occurrence of Holothuria (Holothuria) dakarensis (Holothuroidea: Echinodermata) in the south-western Atlantic, with notes on distribution and ecology. Marine Biodiversity Records, 7; e9. DOI: 10.1017/S17552672140000 49

Prata J., Manso C.L.C. \& Christoffersen M.L. (2014b) Aspidochirotida (Echinodermata: Holothuroidea) from the northeast coast of Brazil. Zootaxa, 3889: 127-150. DOI: 10.11646/zootaxa.3889.1.8

Prata J., Manso C.L.C. \& Christoffersen, M.L. (2016) Occurrence of Ophioderma brevicauda Lütken, 1856 (Ophiuroidea: Echinodermata) from the Brazilian coast. Marine Biodiversity, 47: 1-5. DOI: 10.1007/s12526-016-0584-0

Pyke G.H. \& Ehrlich P.R. (2010) Biological collections and ecological/environmental research: a review, some observations and a look to the future. Biological Reviews, 85: 247-266. DOI: 10.1111/j.1469-185X.2009.00098.x

Riul P., Rodrigues F.M.A., Xavier Filho E.S., Santos R.G., Leonel R.M.V. \& Christoffersen M.L. (2008) Macrocrustaceans from Ponta do Cabo Branco, João Pessoa, Paraíba, the easternmost point of South america. Revista Nordestina de Biologia, 19: 3-13.

Rodrigues F.M.A., Lomônaco C. \& Christoffersen M.L. (2009) Habitat partition, and variations of size and symmetry of three sympatric species of Alpheus (Decapoda: Caridea) along an intertidal gradient in the southwestern Atlantic. Journal of Crustacean Biology, 29: 334-342. DOI: 10.1651/08-3101.1

Santos A.S., Costa D.A. \& Christoffersen M.L. (2008) First record of Scolelepis (Scolelepis) lighti along the Brazilian coast. Journal of the Marine Biological Association of the United Kingdom, 2: 1-5. DOI: 10.1017/S1755267208000183

Santos A.S., Brasil A.C.S. \& Christoffersen M.L. (2014) Sabellaria and Lygdamis (Polychaeta: Sabellariidae) from reefs off northeastern Brazil including a new species of Sabellaria. Zootaxa, 3881: 125-144. DOI: 10.11646/zootaxa.3881.2.2

Santos A.S., Riul P., Brasil A.C.S. \& Christoffersen M.L. (2011) Encrusting Sabellariidae (Annelida: Polychaeta) in rhodolith beds, with description of a new species of Sabellaria from Brazilian coast. Journal of the Marine Biological Association of the United Kingdom, 91: 425438. DOI: $10.1017 / \mathrm{S} 0025315410000780$

Santos A.S., Nogueira J.M.M., Fukuda M.V. \& Christoffersen M.L. (2010) New terebellids (Polychaeta: Terebellidae) from northeastern Brazil. Zootaxa, 2389: 1-46.

Senna A.R., Figueiró R., Andrade L.F., Sardella C.J.R., Guedes-Silva E., Souza-Filho J.F., Miranda G.S., Oliveira G.R., Ferreira R.L. \& Docile T.N. (2013) A importância e os desafios para o conhecimento e a catalogação da biodiversidade no Brasil. Acta Scientiae \& Technicae, 1(1): 53-86.

Stock J.H. (1968) Pycnogonida collected by the Galathea and Anton Bruun in the Indian and Pacific Oceans. Videnskabelige Meddelelser fra dansk naturhistorisk Forening, 137(1): 7-65.

Stock J.H. (1992a) Pycnogonida from southern Brazil. Tijdschrift voor Entomologie, 135: 113140.

Stock J.H. (1992b) Littoral Pycnogonida from Oman. Bijdragen tot de Dierkunde, 62(2): 81-98. 


\section{Pycnogonida from the CIPY}

Veloso V.G. \& Melo G.A.S. (1993) Taxonomia e distribuição da família Porcellanidae (Crustacea, Decapoda, Anomura) no litoral brasileiro. Iheringia, 75: 171-186.

Winston J.E. (2007) Archives of a small planet: The significance of museum collections and museum-based research in invertebrate taxonomy. Zootaxa, 1688: 47-54.

Young P.S. \& Christoffersen M.L. (1984) Recent coral barnacles of genus Ceratoconcha (Cirripedia: Pyrgomatidae) from northeast Brazil. Bulletin of Marine Science, 35(2): 239-252.

Zaher H. \& Young P.S. (2003) As coleções zoológicas brasileiras: panorama e diagnóstico atual e perspectivas para o futuro. Ciência e Cultura, 55(3): 24-26. 